\title{
EUROPEAN STRUCTURAL FUNDS SUPPORT TO FURTHER TRAINING AND INCREASING COMPETITIVENESS OF PEDAGOGUES OF LATVIA
}

\section{SUMMARY}

Introduction. Attraction of funds from European social funds for increasing economic and professional competitiveness of teachers of Latvia is strategically important.

Aim of the Study. To research the options to increase the efficiency of education management in Latvia.

Materials and Methods. The research carried out by the authors of the article is based on study of documents on human resources and education development planning, on study and analysis of experience at attracting the European Structural Funds for supporting teachers of various subjects in Riga and several Latvian regions.

Results. The research shows that support of target scholarships to pedagogues is necessary ensuring the procedure of teaching process at schools and raising the pedagogues' competitiveness in the labour market.

Conclusions. It is possible to conclude that teachers' work motivation is increased, growth of their professional proficiency is facilitated, and new teaching methods are used.

Key words: education management, European Structural Funds, pedagogues'further education, competitiveness

\section{INTRODUCTION}

Changes in public life, in management of national economy industries form new experience, facilitate formation of new conclusions, and test the correspondence of management theories with the character of modern life. Education and an educated person becomes the precondition of wellbeing and public development. A teacher whose activity is supplemented by efficient management of teaching process at school is and remains the central figure of education. It should be noted that management competency in management of teaching processes is significant not only for a head of the school, his deputies, support personnel, but also for a teacher who chooses teaching methods, teaching aids, forms pupils' possible competitiveness in the labour market in several years, affects formation of pupils' personalities, set of values, stabilises a pupil's autonomous learning already during the school time, as well as in the following years. Quality of a pedagogue's activities is a complicated and complex concept where we include professionalism, motivation, communicability and social interrelation, creativity, interest in research. The $21^{\text {st }}$ century needs a person who has not only acquired knowledge, but can also think and act creatively. Thus management of education system should be improved. New working methods, techniques, new work organisation forms are necessary, and what is most important - formation of partnership between all who are involved in the education system - is likewise necessary. In 2001, when only the foundation was laid for the European programme "Education \& Training 2010", in order to successfully implement the 
Lisbon Strategy, the Council of Europe marked guidelines for future development of education accepting teacher development and education and training of their further educators, facilitation of optimal utilisation of resources, support to acquisition of skills that are vitally necessary for formation of a society of knowledge.

\section{AIM OF THE STUDY}

To research options to increase efficiency of education management in Latvia.

\section{MATERIALS AND METHODS}

Jānis Eglītis in his article "Education for Economics of Knowledge" notes, "Education system affects the future of a country, therefore scenarios of development of Latvia should be considered in the context of the present education system and its ongoing processes. The field of education is conservative by its nature, frequent radical changes are not its characteristic trait, likewise an instant efficient solution of the present problems by minor refurbishments in separate elements of education system is impossible" (Eglītis, 2007). J. Eglīis indicates that during secondary education, higher requirements of professional quality than in the elementary school should be set. A situation where natural sciences are taught by a non-specialist or a poorly prepared teacher cannot be allowed. This means that secondary schools need a larger concentration of human resources that is quite problematic in the present economic circumstances. Education should be not only of good quality and available to every resident of Latvia but it also should promote economy development in the country.

Growth of a pedagogue's professionalism is reflected in the pedagogical competency including a set of professional knowledge and high-level proficiency that keep extending while the profession develops within certain norms of behaviour and enriches personal experience. J. Swafford (Swafford, 2000), A. Harris (Harris, 2002) state that improvement of pedagogical competency is mostly based on self-analysis of pedagogues' activity effectiveness, motivation of professional development and professional self-realisation; therefore managers of educational institutions and pedagogues must look forward and be open to various innovations for the educational institution to develop and be competitive, as well as for the pedagogues to be able to incorporate in such rapidly changing circumstances that relate to development of education.

In circumstances of economic crisis, education clearly is the priority of state and society development. Some remarkable books as "Labour Market Research "Compliance of Professional and Higher Education Programmes to Requirements of the Labour Market", (Darba tirgus pētījums "Profesionālās un augstākās izglītības programmu atbilstība darba tirgus prasībām", 2007), "Management of Changes" (Pārmaiņu vadība, 2008) provide some answers of dynamic changes in modern economic and social society impose more various and complicated requirements on pedagogues, schools, educational system and its management. When Latvia became a lawful Member State of the European Union, education and science acquired significantly wider opportunities to attract means from various European funds. Resources of European funds allow implementing plans that did not have free financial means available for a long period of time.

Pedagogues' activity is impossible in social vacuum; it is affected not only by global demands, but also by local social-economic circumstances.

Professor Inese Jurgena from the Riga Teacher Training and Educational Management Academy notes that Latvian society contains a contradiction between pedagogue's varied functions of activities and his personal status. On the one hand, a pedagogue's mission in the society becomes more complicated, on the other hand, payment for pedagogue's work is negligible, status of the 
pedagogue profession in society is low (Jurgena, 2002).

Entering the European Union and rapid globalisation processes influence significantly also the demands for the level of teachers' professionalism. Moreover, demands for education, school and pedagogues become more varied and complicated. The $21^{\text {st }}$ century has begun with rapid social, culture, economic and technology changes not only in Latvia, but also in Europe and globally.

Globalisation tendencies make more attention be drawn to education because education and educational workers play a significant role in implementing changes and new tasks, facilitating the positive and neutralising the negative effect of globalisation. This makes a school and pedagogues follow swift development of most various knowledge fields and teaching approaches, requires creating of circumstances and environment for pupils to acquire skills and be ready for changes, life-long learning and work in the future knowledge society.

In the present situation, contents and movement of a pedagogue's professionalism changes; moreover, changeability and flexibility become the main aspects in contact with the multiple and unforeseeable changes and challenges. A pedagogue must constantly follow and adapt to the new situations to be able to constructively refer to them at any moment maintaining one's prestige and trust of the society.

Development of educational system and implementation of reforms depend on pedagogues. Pedagogues' professionalism may both facilitate and hinder the development of education and whole society depending on its level, pedagogues' attitude towards their profession and their values. Thus the pedagogues' role, their ability and need to learn and develop through the whole life and development of their professional career is the main priority for ensuring quality of education.

A pedagogue's professional proficiency can significantly influence the quality of educational process because the way how educational programmes are implemented and what is the teaching quality depends on the professional proficiency and work quality of each pedagogue (Eiropas Savienības struktūrfondu nacionālās programmas projekts "Pedagogu tālākizglītības metodiskā tīkla nodrošinājuma izveide", 2008).

Many educational and management experts as L. Gratone (Gratone, 2004), I. Ulmane (Ulmane, 2007) speak of school as an institution that learns. Readiness of a school to get involved in innovation indicates that the school is an institution that learns. Readiness of pedagogues to learn, in order to be prepared for changes to ensure improvement of their professional proficiency and their professional career, likewise proves that the respective educational institution is an institution that learns. Readiness of a school to get involved in innovations, projects depends on its pedagogues' readiness to work with the new, often complicated and unpredictable contents (Mālkalne, 2007).

No matter how qualitative would the initial teachers' educational programme and its acquisition would be teachers' further education becomes more and more important. Pedagogues' education and further education draws broad attention in the EU that has facilitates a formation of joint educational management principles:

- pedagogues' education must take place and institutions of the higher education and pedagogues must be provided with a possibility to continue studying at all levels of the higher education in order to develop their professional competency and progress of their professional career in compliance with their abilities and interests;

- a multi-disciplinary approach is necessary for pedagogues' education and further education;

- pedagogues' education and further education should ensure acquisition of knowledge and 
skills in educational sciences and the subject to be mastered, formation of skills and abilities to support pupils and facilitate developments, formation of understanding about social and culture dimensions of education, ability to see research skills, constant improvement of theory knowledge together with the practical pedagogical activity;

- a pedagogue's profession in its essence is life-long education: it requires constant improvement during the whole career. Pedagogues must understand the necessity of new knowledge, must be able to work creatively and cause innovations, must facilitate and form the pupils' readiness for life-long learning;

- nowadays, pedagogues' readiness to work and develop in international context plays a significant role acquiring most various experience in educational institutions of other countries;

- an important role of pedagogues' work is given to cooperation between colleagues, schools, various contact institutions and the society (Eiropas Savienības struktūrfondu nacionālās programmas projekts "Pedagogu tālākizglītības metodiskā tīkla nodrošinājuma izveide", 2008).

In Latvia as a Member State of the EU, pedagogues' options to participate in international circulation - at projects, sharing experience and taking part in practice in other countries - are increasing. Thus managers of educational work should draw more attention to events that would enable pedagogues to actively use these options. Moreover, these options support pedagogues' further education directed to the common space of European education (Mūžizglītības politikas pamatnostādnes 2007.-2013. gadam, 2007).

Alma Harris in her work School Improvement (Harris, 2002) stresses the thought that each teacher has his individual (personal) and professional needs for development. These are affected by the teacher's age, gender, experience, contents of the subject to be taught, environment. A teacher's learning and work as concepts cannot be separated.

With entering the European Union, Latvia started utilising one of the most important possibilities of a Member State of the European Union to use the support of structural funds (SF). Aim of these funds is to eliminate regional and social inequality among EU Member States and their regions, as well as to improve the economic and social cohesion in whole Europe.

Financial means of European Structural Funds is a great benefit to Latvia because they may significantly facilitate formation of a society based on knowledge and development of Latvia on the whole. It must however be remembered that a large funding causes a risk and that inadequate utilisation of these means may only stimulate regional inequality, social ostracism, environmental degradation and corruption. Attraction of additional funds requires control at the state level and the European Union. The European Union has developed binding regulations and normative documents as one of control mechanisms that in the respective planning period regulate utilisation of finances of certain structural funds. At present, Latvia as one of least developed regions of the European Union has the chance to use the financial help provided by the European Union for development and stability of economy sustainability. The largest financial instruments that provide financial aid to Latvia is EU funds: European Regional Development Fund (ERDF); European Social Fund (ESF); Cohesion Fund (CF).

The European Regional Development Fund (ERDF) was established in 1957 to balance regional differences within the Community. Within the framework of this fund, aid is provided to less developed regions, with the main focus on improvement of public infrastructure and facilitation of business. 
The European Social Fund (ESF) was formed in 1957 and its target is to facilitate employment in European Union Member States, to eliminate all kind of discrimination and inequality in labour market, as well as to develop human resources and support formation of information society (Eiropas Sociālais Fonds izglītībai, 2008).

Cohesion Fund (CF) is one of financial instruments of EU regional policy with the aim to equalise economic and social differences existing among countries. It was established to finance largescale infrastructure development events (projects) in the field of environment protection and transportation. The fund provides financial investment in project to achieve the targets set by the EU in the fields of environment and transportation, to implement EU policies and meet the requirements determined by directives.

On December 18, the European Commission has approved an Operational Programme for the period of 2007-2013: Human resources and Employment (Darbības programma „Cilvēkresursi un nodarbinātība", 2008), within the framework of which there is 550.7 million euro available for Latvia from the European Union budget. The programme is financed from the ESF and it is aimed at development of education and science, employment and promotion of social alignment, creation of healthy labour force, as well as strengthening of administrative capacity. The European Commission has approved all three operational programmes submitted by Latvia, as well as strategic basis for EU fund utilization in 7 year period - Latvian National Strategic Reference Framework. With this decision Latvia can start implementation of EU funds in the planned fields - education and social care.

A significant investment of financing from the structural funds is planned into education and science during the new EU structural funds planning period from 2007 to 2013. The total planned investment from EU structural funds and national public finances is more than 880 million EUR; most of this sum is allocated for facilitating development of education - 542 million EUR. During the new period, financing
Picture 1. Division of total financing of EU funds in 2007-2013 (EU fund planning)

(ES fondu finansēšana. Finansējuma sadalījums pa nozarēm, 2009)

Division of financing according to industries of the total financing in the amount of

LVL 3.18 billion (EUR 4.53 billion)*

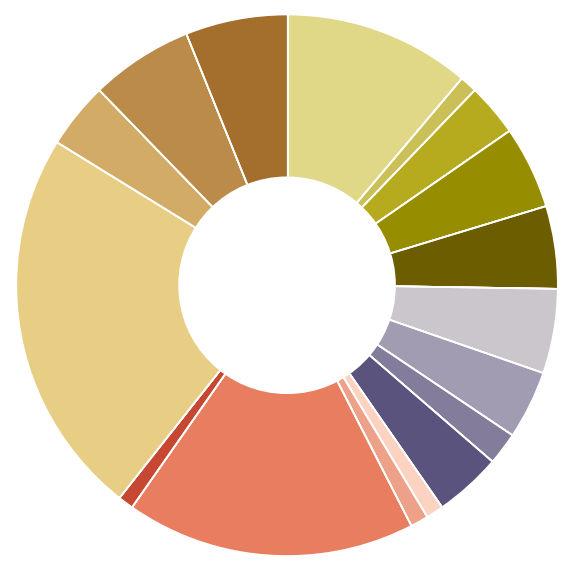

Education - LVL 359 million

Administrative capacity - LVL 37 million

Technical aid - LVL 80 million

Health - LVL 174 million

Employment - LVL 165 million

Science - LVL 167 million

Innovations - LVL 143 million

Facilitation of competitiveness - LVL 71 million

Financial events - LVL 119 million

Tourism - LVL 30 million

Social-economic influence of the cultural environment - LVL 30 million

Environment - LVL 557 million

Energoefficiency of the dwelling - LVL 21 million

Transportation and infrastructure - LVL 725 million

Information society - LVL 133 million

Development of city environment - LVL 185 million

Sustainable development - LVL 190 million 
of the EU structural funds for education and science basically is planned in order to reach the strategic target of the National Development Plan - to form a develop Latvian economy on the basis of distinction of science and technologies. Under the mentioned target, a systemic support of the EU funds to general, professional, higher education and life-long education is planned stressing modernisation of natural sciences and engineering, as well as facilitating development of including education and providing each person with options to study in compliance with requirements of the labour market during the whole life.

Table 1. Division of allocated EU structural funds and Cohesion Funds among thematic axes and events of the project of state strategic framework document for 2007-2013 (ES fondu finansēšana. Finansējuma sadalījums pa nozarēm, 2009)

\begin{tabular}{|l|l|l|l|l|}
\hline Fund & $\begin{array}{l}\text { European Community } \\
\text { financing (EUR) }\end{array}$ & $\begin{array}{l}\text { Latvian co-financing } \\
\text { (EUR) }\end{array}$ & $\begin{array}{l}\text { Total financing } \\
\text { (European Community + } \\
\text { Latvia) (EUR) }\end{array}$ & $\begin{array}{l}\text { \% of SF and } \\
\text { CF }\end{array}$ \\
\hline ERDF & $2,440,017,364$ & $678,489,839$ & $3,118,507,203$ & $53.86 \%$ \\
\hline ESF & $550,653,717$ & $106,304,333$ & $656,958,050$ & $12.15 \%$ \\
\hline CF & $1,539,776,553$ & $438,315,608$ & $1,978,092,161$ & $33.99 \%$ \\
\hline TOTAL: & $4,530,447,634$ & $1,223,109,780$ & $5,753,557,414$ & $100.00 \%$ \\
\hline
\end{tabular}

By support from the ESF, implementation of the European Human Resources development and employment strategy is being carried out. The ESF facilitates and supports activities of Member States for development of labour market and human resources, included in long-term human resources development plan developed by the Member States because Europe has:

- a large proportion of pupils with a low level of basic skills and insufficient proportion with a high level of competencies;

- a disproportion in choice between general education and professional education after the elementary school;

- a content of professional education, pedagogues' competency and quality of implementing programmes that still does not correspond to requirements of the labour market;

- huge disproportions in the number of students and prepared specialists - more that a half of students study social sciences, natural sciences, engineering, technologies, medicine and health care studies have a deficiency of students;

- aging of pedagogues and academic personnel and lack of new teaching staff;

- poorly developed system of informal education because the offer of life-long learning is insufficiently professionally oriented;

- insufficient participation of employers in development of human resources;

- insufficient proportion of such educational institutions that provides access to students with special needs, as well as insufficient integration of children and youth with functional disorders in the total flow of education (Darbības programma „Cilvēkresursi un nodarbinātība”, 2008).

Financing of the Operational Programme "Human Resources and Employment" (see Picture 2) Amounts to EUR 550,653,717 or $12.2 \%$ of the total financing off 4.5 billions (EUR 4,530,447,634) for 2007-2013. 
On 30 April 2008, the State Agency for Development of Education and Study Fund entered into a contract on allocation of 11.24 million lats to the EU Social fund "Support to Ensure Pedagogues of General Education in the Priority Subjects" (agreement No 2008/0001/1DP/2.1.2.2./ 08/IPIA/VIAA/002) stimulating payment of target scholarships to teachers of natural sciences, maths, information technologies and foreign languages (ESF projekts „Atbalsts vispārējās izglītības pedagogu nodrošināšanai prioritārajos mācību priekšmetos", 2009).

Aim of the project is to eliminate lack of pedagogues as well as to increase the teaching and learning quality of the following subjects in the general education:

- natural sciences (physics, chemistry and biology),

- maths, information technologies,

- foreign languages (official languages of the European Union of the European Economic Area).

Task of the project is to allocate and pay target scholarships to pedagogues who teach the above subjects and study at the same time in order to acquire the qualification necessary for the job, or else perform additional work on methods for popularisation of the subject and improvement of teaching quality. The total costs of the project amount to LVL 11,244,864, including the cofinancing of the European Social Fund in the amount of LVL 9,558,134 and financing from the state budget in the amount of LVL 1,686,730, as can be seen in the breakdown in Picture No 3.

\section{RESULTS}

Total number of target scholarships in the middle of 2009 is 2193 that serves as financial support to more than $6 \%$ of pedagogues working in the country. Picture No 4 summarises information on division of target scholarships according to districts and cities.

It has been determined that pedagogues are given the target scholarships for one academic year and it can be received for a period of 10 months. Each academic year, the pedagogue may repeatedly apply for the target scholarship. The pedagogue
Picture 2. Division of financing of "Human Resources and Employment" \% (Darbības programma ,, Cilvēkresursi un nodarbinātība”, 2008)

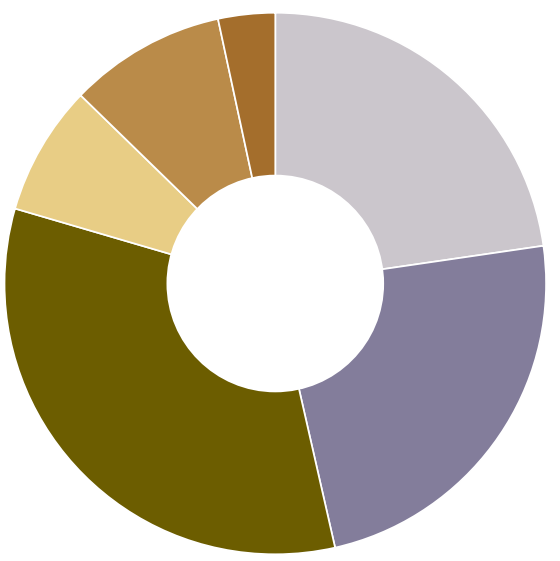

Higher education and science $-22.9 \%$

Education and skills - 23.5\%

Facilitation of employment and Health at work - $33.1 \%$

Facilitation of social incorporation $-7.7 \%$

Strengthening administrative capacity $-9.5 \%$

Technical support $-3.3 \%$

Picture 3. Total costs of the project $\%$ (ESF projekts „,Atbalsts vispārējās izglìtības pedagogu nodrošināšanai prioritārajos mācību priekšmetos”, 2009)

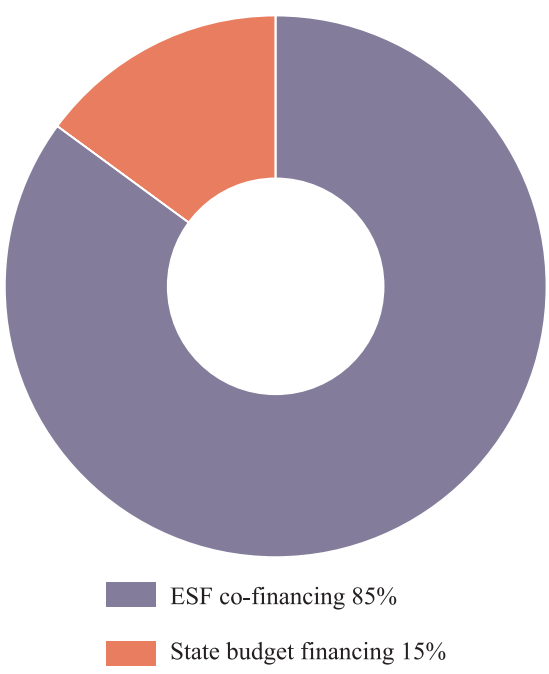


may receive the target scholarship not more than three years - not exceeding 30 months. The pedagogue has to submit a report about his activities once in a half-year. If the work has not been accomplished, the agreement is terminated and payment of target scholarship is suspended.

The target scholarship is granted according to the following priority order and amount:

A scholarship of 100 lats per month can be received by pedagogues working in grades 7 to 12 who study in the corresponding study programme and at the same time teach the priority subjects 12 contact-lessons a week.

A scholarship of 65 to 150 lats can be received by pedagogues of grades 7 to 12 who have acquired professional qualification in the corresponding study programme, teach a priority subject or subjects from 9 to 21 or more contact-lessons a week and carry out four additional tasks of research or creative work.

Pedagogues from all districts and cities of Latvia have applied for the Project except Ventspils district. The largest number of target scholarships has been granted to Riga pedagogues - 566, and in Riga district, 117 target scholarships have been allocated to pedagogues.

In the academic year of 2007/2008, 78 pedagogues in Jelgava city received target scholarships, in Dobele district - 23. No target scholarships were given in the academic year of 2007/2008 to pedagogues in Tukums district and Riga. In the academic year of 2008/2009, the number of granted target scholarships was as follows: in Riga - 571, Jelgava - 72, Dobele district -37 and Tukums district -57 . These data show a tendency that the number of pedagogues, who apply for the target scholarships, is increasing, thus pedagogues become more interested in arranging extra events that facilitate improvement of education quality.
Picture 4. Number of scholarships in districts and cities
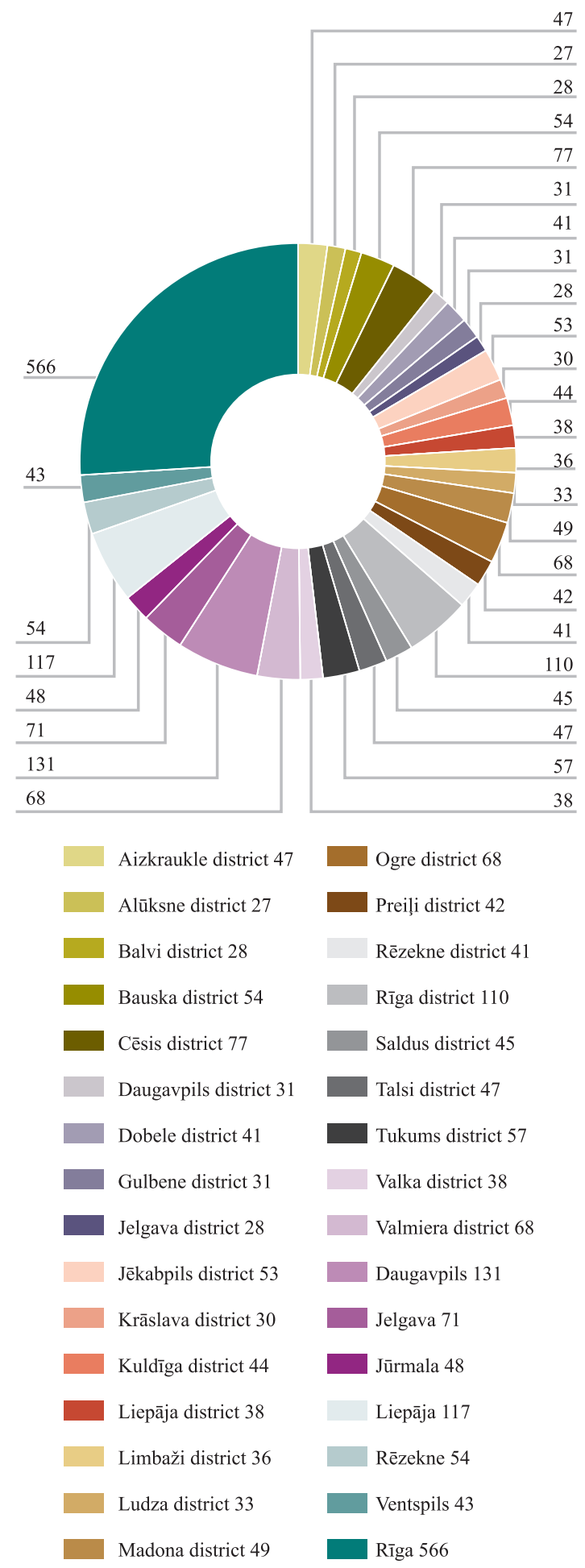
Picture 5. Distribution of target scholarships of pedagogues according to subjects in the academic year of 2008/2009

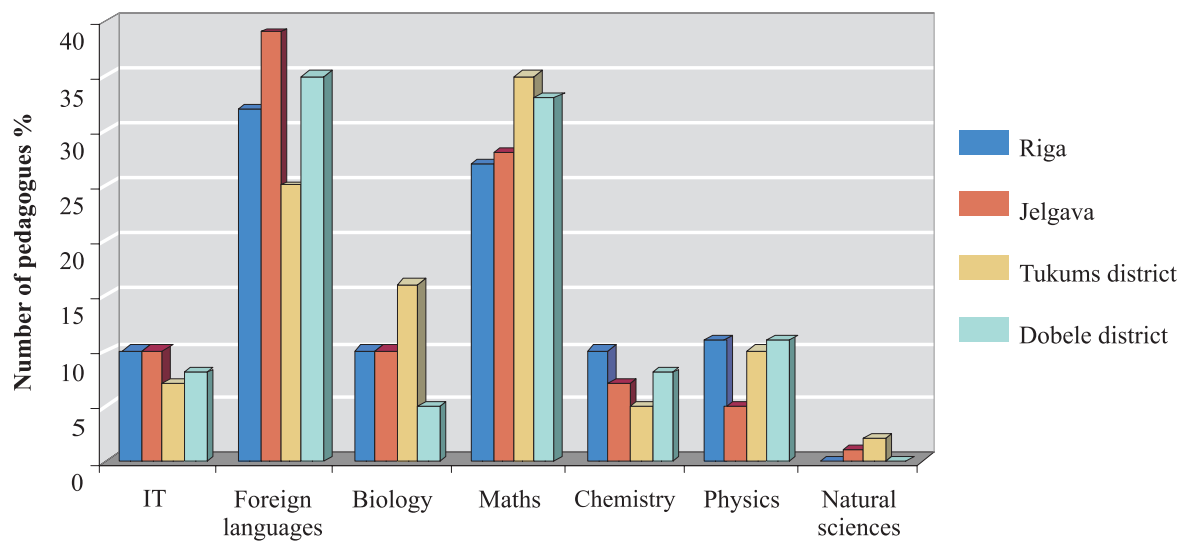

The largest number of pedagogues in the academic year of 2008/2009 receiving the target scholarship in priority subjects is pedagogues teaching English and Maths.

Evaluating the pedagogue's extended work plans for the planned research or creative tasks in the academic year of $2008 / 2009$, it can be concluded that $17 \%$ of pedagogues choose activity 3.3 that includes use of information technologies for improvement of acquisition of a priority subject, $15 \%$ choose activity 5 that includes facilitation of understanding of equal possibilities in education and career and decreasing stereotypes of the influence of gender in choice of profession, $14 \%$ choose activity 3.1 that includes improvement of teaching methods of the subject, $12 \%$ choose activity 4.1 that is thematic consultations for facilitation of learning motivation of pupils, improvement of learning results, and activity 6.2 th hat includes management or research work of pupils in the respective subject, $11 \%$ choose activity 4.2 that includes organising events for facilitating pupils' interest in the respective subject. $8 \%$ of pedagogues choose activity 4.3 that

Picture 6. Division of activities in per cent of projects by Jelgava city pedagogues in the academic year of 2008/2009
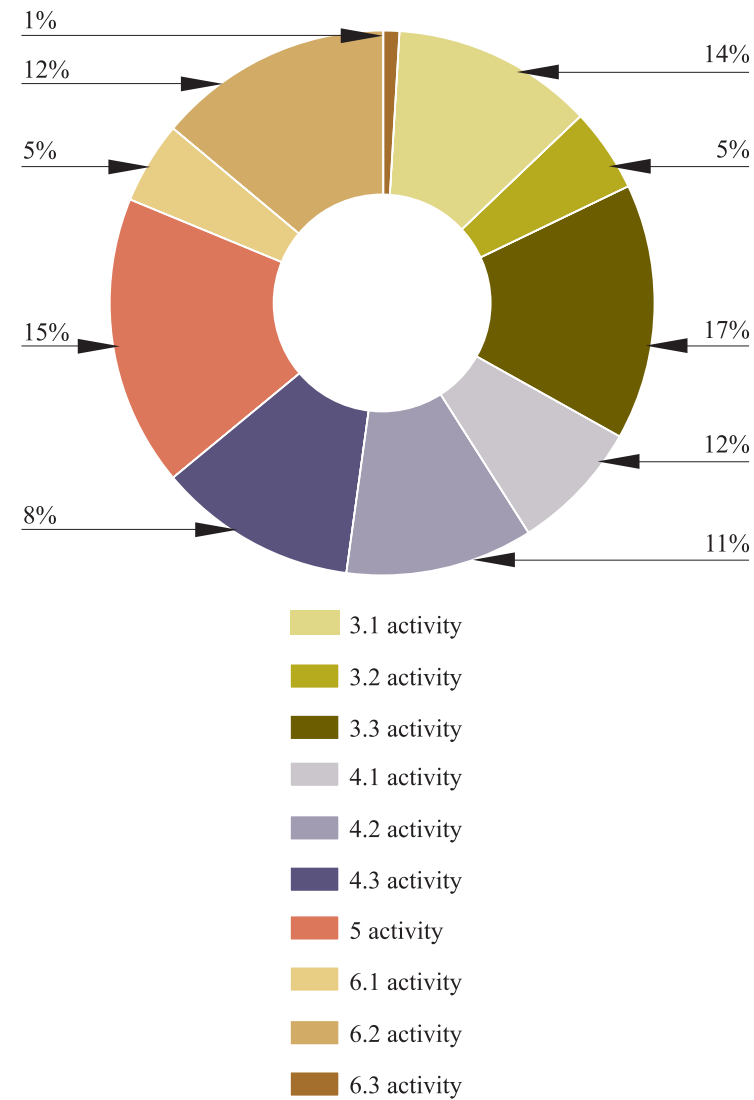
is transfer of gained experience to pedagogues working at the respective subject or methodical consultations to young pedagogues, $5 \%$ choose activity 3.2 that is approbation of new teaching aids at an educational institution and activity 6.1 that is a research work in pedagogy or educational science. Least, that is: $1 \%$ of pedagogues chooses activity 6.3 that provides for management of praxis of the pedagogues to become. All in all it can be concluded that pedagogues draw attention at first to activities that facilitate quality of education.

Themes of teachers' practical conference in Riga, on 26-30 June 2009 (ESF projekts „Atbalsts vispārējās izglītības pedagogu nodrošināšanai prioritārajos mācību priekšmetos”, 2009) show a confirmation to the above conclusions that pedagogues stress activities of methodical work, introduction of information technologies to lessons, visualisation of thematic work-out of the subject and interactive teaching methods. It is understandable that activities that gain a faster feedback (pupils' knowledge and skills) are preferred. Having accumulated the necessary experience for implementing and managing projects, pedagogues will be able to address management of students' pedagogical praxis, research, and selfeducation.

\section{CONCLUSIONS}

Within the scope of this article it is not possible to extensively review pedagogues' further education and activity nuances of the support, however, it is possible to study the directions of education management and human resources management and the possible results.

The largest financial instruments providing financial support to Latvia are the European Funds - European Regional Development Fund (ERDF); European Social Fund (ESF); Cohesion Fund (CF). For 2007.-2013., financing from EU structural funds for education and science basically plans a support to general, professional, higher education, as well as life-long learning, stressing modernisation of natural sciences and engineering, facilitating development of the inclusive education in compliance with requirements of the labour market during the whole life in order to gain the strategic target of the National Development Plan - to form a developed economy of Latvia on the basis of distinctive science and technologies.

The number pedagogues who apply for target scholarships is increasing, thus pedagogues become interested in carrying out additional tasks that facilitate their further education, professional readiness, improvement of the quality of education. Simultaneously experience of teachers of general education subjects is acquired regarding acquisition of resources of European Funs, regarding performance and management of project work. Availability of resources covers whole Latvia in geographic sense, although teachers who have comparatively large number of contact-lessons in the respective subject are preferred. All pedagogues need support to increase the quality of education not only in the large educational institutions.

Granting of target scholarships promotes pedagogues' competitiveness in the labour market. In the tense economic circumstances in the Latvian education, use of resources from the European Funds forms a foundation for a stable and sustainable development of educational system.

Of project activities, pedagogues prefer use of information technologies in increasing the quality of teaching process $(17 \%), 15 \%$ choose activity 5 that is promotion of understanding on equal opportunities in education and career and decrease in stereotypes on gender influence on choice of profession, $14 \%$ choose activity 3.1 that is improvement of teaching methods of a subject. 
Attraction of resources from European Structural Funds for pedagogues' further education in Latvia and facilitation of competitiveness is a significant investment in improvement of quality of general education.

\section{REFERENCES}

1. Darba tirgus pètījums "Profesionālās un augstākās izglìtības programmu atbilstība darba tirgus prasībām” (2007) [Labour Market Research "Compliance of Professional and Higher Education Programmes to Requirements of the Labour Market"]. Rīga: Latvijas Universitāte, 231 lpp. (in Latvian).

2. Darbības programma „Cilvēkresursi un nodarbinātība" (2008) [Operational Programme "Human Resources and Employment”]. Rīga: LR Finanšu ministrija, http://www.esfondi.lv/upload/04-kohezijas politikas_nakotne/op/1_dp_2008-08-29.pdf (30.06.2009.) (in Latvian).

3. Eglīitis, J. (2007) Izglīî̄ba zināšanu ekonomikai. Izglītība zināšanu sabiedrības attīstībai Latvijā, Zinātniski pētnieciskie raksti 2 [Education for Economics of Knowledge. Education for Development of Knowledge Society in Latvia. Scientific-research articles 2], Rīga: Zinātne, 142.-162. lpp. (in Latvian).

4. Eiropas Savienības struktūrfondu nacionālās programmas projekts "Pedagogu tālākizglītības metodiskā tīkla nodrošinājuma izveide”" (2008) Nr. 2006/0129/VPD1/ESF/PIAA/06/NP/3.2.5.1./0001/ 0001/0504. Materiālu krājums [Project of National Programmes of the European Union Structural Funds. Formation of Coverage of Methodical Net for Pedagogues' Further Education]. (in Latvian).

5. Eiropas sociālais fonds izglītībai (2008) Valsts izglìtības attīstības aǵentūras ziņu izdevums 11-12, 2008 [European Social Fund for Education. State Edition of News of Agencies of Education Development], 4.-5. lpp. (in Latvian).

6. ES fondu finansēšana. Finansējuma sadalījums pa nozarēm (2009) [Financing from the EU Funds. Division of Financing According to Fields] http://www.esfondi.lv/page.php?id=633 (30.06.3009.) (in Latvian).

7. ESF projekts „Atbalsts vispārējās izglītības pedagogu nodrošināšanai prioritārajos mācību priekšmetos” (2009) Skolotāju praktiskā konference. Anotāciju krājums [ESF project "Support to Ensure Pedagogues of General Education in the Priority Subjects" Teachers' Practical Conference. Collection of Annotations]. Rīga, 30 lpp. (in Latvian).

8. Gratone, L. (2004) Cilvēkresursu stratēgija [Human Resources Strategy]. Rīga: Jumava, 284 lpp. (in Latvian).

9. Harris, A. (2002) School Improvement. What's in it for schools? London and New York: Routledge/ Falmer, $135 \mathrm{p}$.

10. Jurgena, I. (2002) Vispārīgā pedagogija [General Pedagogy]. Rīga: Izglīīibas soḷi, 144 lpp. (in Latvian).

11. Mālkalne, V. (2007) Pedagogu profesionālās meistarības pilnveide [Development of Pedagogues' Professional Proficiency], Skolotājs 2 (62), 82.-88. lpp. (in Latvian).

12. Mūžizglītības politikas pamatnostādnes 2007.-2013. gadam (2007) [Guidelines of Life-Long Learning Policy]. http://www.muzizglitiba.lv/view 52587.html (30.06.2009.) (in Latvian).

13. Pārmaiņu vadība (2008) [Management of Changes]. Rīga: Lietišķās informācijas dienests, 160 lpp. (in Latvian). 
14. Swafford, J. (2000) Teachers Supporting Teachers through Peer Coaching. In: Leading Professional Development in Education, (Eds.) B. Moon, J. Butcher, E. Bird, London: The Open University Press, $336 \mathrm{p}$.

15. Ulmane, I. (2007) Projektu sagatavošana inovācijām izglītības iestādē [Preparation of Projects for Innovations in an Educational Institution], Skolotājs 4 (64), 50.-57. 1pp. (in Latvian).

Associate professor Dr. paed. Valdis Krastiņš

Riga Teacher Training and Educational Management Academy

Address: Andromedas gatve 7-87, Rīga

Phone: +37129501283

E-mail: valdis.krastins@rpiva.lv

Lecturer Mg. sc. soc. Vairis Ļaudams

Riga Teacher Training and Educational Management Academy

Address: Bērzu iela 8, Dobele, Latvija

Phone: +37129140154

E-mail: vairis.laudams@inbox.lv 